\title{
THE FAITHFUL COPY AS A MEDIUM OF APPROPRIATION AND PROPAGANDA
}

\section{French Commissions after Leonardo's Last Supper*}

In April 1807 Eugène de Beauharnais, the French vice-regent of Italy, commissioned Giuseppe Bossi to copy Leonardo's Last Supper (1494-1498, fig. 1). ${ }^{1}$ Since the Milanese painter found the famous masterpiece to be in a poor state of repair, he began his work by locating and analysing existing copies. Three years later he produced a pioneering comprehensive study of the mural in Santa Maria delle Grazie, in which he also described the numerous replicas it had engendered. ${ }^{2}$ It was not, however, until the beginning of the $20^{\text {th }}$ century, that art historians analysed copies of the Cenacolo in order to better appreciate Leonardo's original and to comprehend its impact on Lombard art. ${ }^{3}$ Finally, after the Second World War, these copies were re-evaluated from the perspective of social and economic art history and appreciated in their context. Accordingly, researchers regarded them as works displaying individual iconographical or stylistic features which could be considered as expressions of criticism towards Leonardo's original. ${ }^{4}$ Some exhaustive studies on individual copies were also carried out on occasion of their respective restoration, ${ }^{5}$ while a significant number of these replicas produced by Italian

* I would like to warmly thank Frédéric Elsig, Gerard Mannion, Adam Stewart Massie and the editors of the present volume, in particular Antonia Putzger and Marion Heisterberg, for their reading of this article and their useful comments and suggestions.

1 His painted canvas was destroyed during the bombing of the Castello Sforzesco in 1943 while the transfer cartoons he drew were used by Giacomo Raffaelli to realise a mosaic version of the Last Supper, which is today kept in the church of the Minorites in Vienna (cf. Samek Ludovici 1971, 315). After Bossi's death the transfer cartoons were acquired by Grand Duke Carl August of SaxonyWeimar-Eisenach and are still existent within the holdings of the Klassik Stiftung Weimar (cf. Antonelli 1995; exh. cat. Weimar 2016).

2 Bossi 1810. The author dedicated his book to the Duke of Lodi, whose forefather was one of Leonardo's favourite pupils, Francesco Melzi.

3 Bertoglio Pisani 1907; Hoerth 1907, 17-19 and 234-243; Malaguzzi Valeri 1915, 534-557; Horst 1930-1934, 118-200.

4 Möller 1952, 109-169; Steinberg 1973, 402-410; Rossi/Rovetta 1988, 76-95.

5 Marijnissen 1959; Shell/Brown/Brambilla Barcilon 1988. 


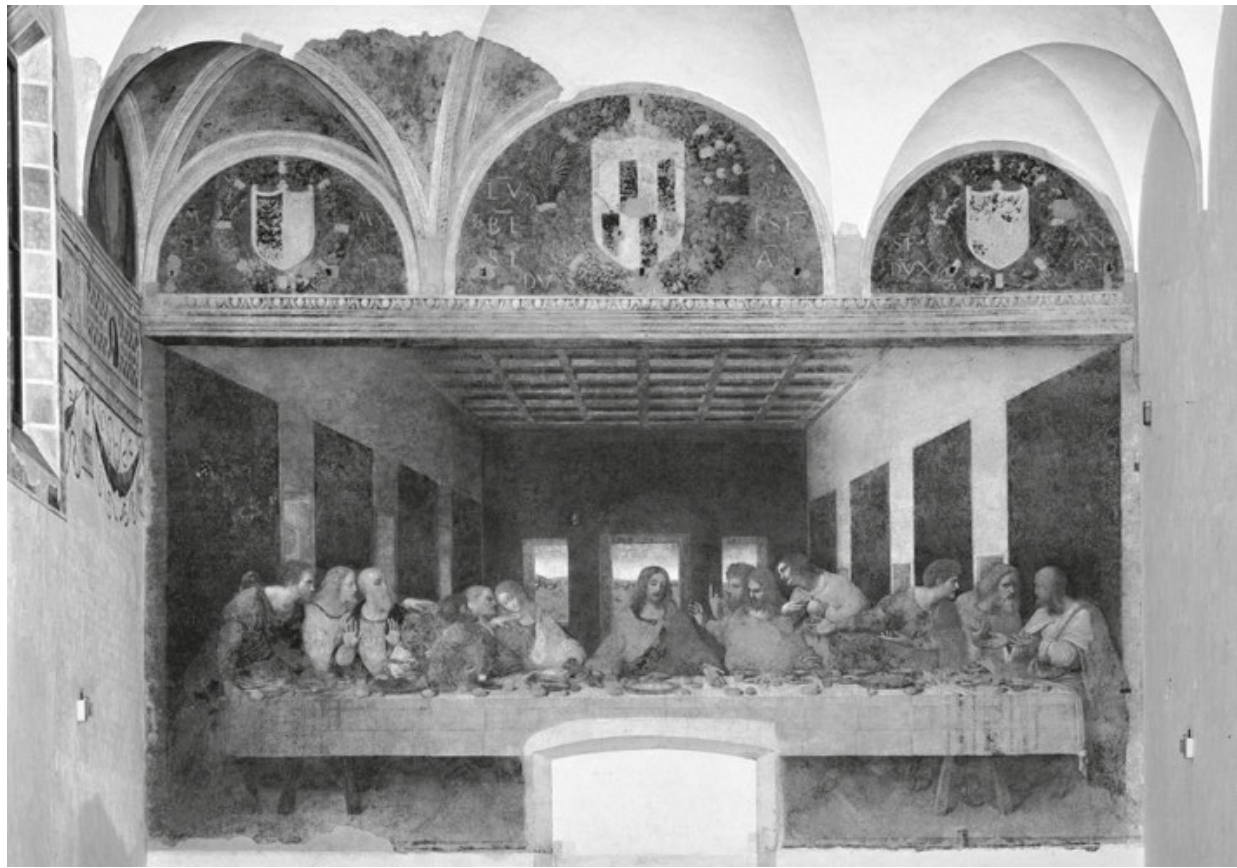

1 Leonardo da Vinci, The Last Supper and the three lunettes with the Sforza's blazons, 1494-1498, tempera and oil colours on two preparation layers, $460 \times 880 \mathrm{~cm}, 243 \times 143.5 \mathrm{~cm}$ (lunette to the left), $350 \times 201 \mathrm{~cm}$ (in the middle), $246 \times 147 \mathrm{~cm}$ (to the right), Milan, Refectory of Santa Maria delle Grazie

and Northern European artists in varying media have been featured in the course of two exhibitions. ${ }^{6}$

In the late $1980 \mathrm{~s}$, a notable contribution to the study of Lombard artistic production based on archival research was made by Shell and Sironi, who published unedited extracts dealing with various commissions of copies of the Last Supper.7 Finally, in her doctoral thesis on Leonardo en France, published in 2009, Laure Fagnart focused on the replicas ordered during the first decades of the $16^{\text {th }}$ century by the French governors of Lombardy. ${ }^{8}$ She considered their networks and links with the dukedom, highlighting the emulative reasons for their commissions. Taking Fagnart's noteworthy research as a starting point, this article aims to explore the question of how the construction of French political and cultural identity was related to Lombard artistic production. It pursues the assumption that the political motivations and implications of these French commissions

\footnotetext{
Exh. cat. Washington 1983; exh. cat. Milan 2001.

Sironi 1988; Shell/Sironi 1989; Shell 1995.

8 Fagnart 2009.
} 
were dependent on the peculiar historical context of the conquest of Lombardy and the tense relationship between Louis XII and Ludovico Sforza who, in 1494, had commissioned Leonardo da Vinci to paint the Last Supper in the Dominican monastery of Santa Maria delle Grazie. ${ }^{9}$

Within this article, we will retrace the strong impact and the fascination exerted by Leonardo's mural on his contemporaries in order to briefly recall its artistic innovations. Following this, four copies commissioned by French dignitaries during the reign of Louis XII - in particular from the conquest of the Duchy of Milan in 1499 to its loss in 1512 will be reconsidered with particular respect to their similarities to the original in Santa Maria delle Grazie. The question will be posed if the recognisable formal faithfulness of the copies can be related to the political appropriation of the Lombard duchy government by the French king and his allies.

\section{Leonardo's Last Supper: an early response}

In Lombardy, comments on Leonardo's mural seem to have circulated even whilst the painting was still incomplete. In his Novelle, published in 1554, Matteo Bandello recounts the long hours spent by the Florentine master contemplating and meditating on his work and tells of how he left the equestrian clay monument he was moulding for the Duke of Milan in order to travel to Santa Maria delle Grazie to work on his mural, just to run off again after a few strokes of his brush. Sometimes, while the artist was painting, gentlemen of the court would enter the refectory and silently contemplate the miraculous and famous masterpiece. ${ }^{10}$ In his Vite (1550/1564) Giorgio Vasari reports how Leonardo was continually harassed by the Dominican prior of the monastery who complained to the Duke about the painter's slowness. Allegedly, Leonardo rewarded the unfortunate priest by portraying him as the traitor Judas Iscariot in his mural, while Christ's face was left unfinished on purpose, since the artist considered himself unable to give it the required godly grace and beauty. ${ }^{11}$ If these anecdotes were already known at the time of the painting's execution they must have raised great expectations and curiosity among the Milanese population.

Leonardo's friend, the Florentine mathematician Luca Pacioli, praised the mural upon its completion in 1498 in the dedication of his De Divina Proportione to Ludovico Sforza (thereby indirectly praising the Duke as the patron):

9 Malaguzzi Valeri 1915, 486-488. On Santa Maria delle Grazie see the recent symposium proceedings Buganza/Rainini (eds.) 2017.

10 Bandello (Maestri) 1992, 513. Matteo Bandello's uncle, Vincenzo, was the prior of Santa Maria delle Grazie at the time Leonardo was painting the Last Supper. In 1497, the young Matteo - aged 12 entered the convent, where he received his first education and where he personally met the Florentine master (Sapegno, 1963, 668).

11 Vasari (Dent) 1949-1950, vol. II, 160-162. 
Ohimè, chi è quello che vedendo una ligiadra figura con suoi debiti liniamenti ben disposta, a cui solo el fiato par che manchi, non la giudichi cosa più presto divina che umana? [...] non è possibile con maggiore attentione vivi gli apostoli imaginare al suono de la voce de l'infallibil verità, quando disse: unus vestrum me traditurus est. Dove con acti e gesti l'uno a l'altro, e l'altro a l'uno con viva e afflicta admiratione par che parlino, sì degnamente con sua ligiadra mano el nostro Lionardo lo dispose..$^{12}$

Pacioli emphasised the divine - more than the human - nature of the painting by adopting a famous humanist topos according to which the figures appeared so lifelike as to be talking to one another, seemingly just lacking breath to live.

However, apart from the stylistic features which strongly contributed to the overall impression of reality (and many other elements relative to the painting's construction and composition which we cannot broach here), perhaps the greatest of Leonardo's innovations lay in the iconographical choice of the specific moment he depicted. ${ }^{13}$ Moreover, his monumental mural, occupying the whole north wall of the refectory in Santa Maria delle Grazie, was painted to be perceived, in linear perspective, as an extension of the actual room in which the Last Supper was held. Christ and the Apostles seemed therefore not only to be sharing their meal with the Dominican monks - as the tradition of Treand Quattrocento refectory decoration implies - on an imaginary level but also within continuous spatial dimensions. Pacioli's wonder at the figures' liveliness is therefore more than just a topos and his comment on the painting's divine nature was later recalled by Sabba da Castiglione (1554) and stressed by Billi (ca. 1520), Bandello (1554), Bugatti (1570), Bocchi (1584) and Armenini (1587), who regarded the picture as "miraculous" from an aesthetic point of view. ${ }^{14}$ Promoted by these and other written as well as oral comments, the renown of the Last Supper soon spread throughout Lombardy and Italy, which may have contributed to its appreciation by the French upon conquering Milan.

12 Pacioli, Luca: De divina proportione, 1498 (Milan, Biblioteca Ambrosiana, ms. 1499). The quotation is reported in Bossi 1810, 14.

13 It is well known that, instead of representing the traditional apostles' Holy Communion (interpreted as the institution of the Eucharist) or the identification of Judas as the betrayer, Leonardo focused on the moment immediately following Jesus' dramatic and shattering statement "Verily, verily I say unto you that one of you shall betray me" (John 13,21). Unsurprisingly this announcement provokes horror and astonishment among the Apostles, as is also related by the Gospels. Accordingly, in his Cenacolo Leonardo explored the wide range of attitudes, gestures and expressions provoked by the mot $i$ dell'animo, the motions of the soul that affect facial features and body language (cf. Leonardo's $A$ Treatise on Paintings, which was published after the death of the artist, Vasari [De Rossi] 1817, $80 \mathrm{f}$. Before, similar concepts had also been expressed in Leon Battista Alberti's Della pittura [1435], cf. Alberti [Mallé] 1950,93-95). The Florentine master depicted each disciple's emotional and temperamental reaction fitting to the disposition attributed to them in the Gospels and in hagiographical texts. Thus the figure of Christ stands in contrast to their shaken expressions and, conscious of his destiny, remains peaceful and composed in the middle of the scene (Rossi/Rovetta 1988, 76-95; Marani/Cecchi/Mulazzani 1999, 11-44; exh. cat. Milan 2001, 63-101).

14 On the critical fortune of Leonardo's Last Supper see the exh. cat. Milan 2001, 29-38. 


\section{After the French conquest of the Duchy of Milan}

At the beginning of September 1499, the French army, led by Louis de Luxembourg and Gian Giacomo Trivulzio, conquered the Duchy of Milan. On October 6, King Louis XII entered the city in triumph. Albeit with some interruptions, Lombardy was occupied and ruled by the French for about twenty years. ${ }^{15}$ During this period, the painting in Santa Maria delle Grazie aroused the keen interest of French dignitaries. According to Paolo Giovio, Leonardo's first biographer writing in 1527, the king himself was so taken by Leonardo's painting that, wishing to possess it, he even demanded it to be removed from the wall in order to send it to France:

In admiratione tamen est Mediolani in pariete Christus cum discipulis discumbens, cuius operis libidine adeo accensum Ludovicum regem ferunt, ut anxie spectando proximos interrogarit an circumciso pariete tolli posset, ut in Galliam vel diruto eo insigni cænaculo protinus asportaretur. $^{16}$

This episode was later reported by Francisco de Hollanda in his De Pintura Antigua $(1548)^{17}$ and also by Giorgio Vasari in his Lives:

The nobility of this painting, in its composition and the care with which it was finished, induced the King of France to wish to take it home with him. Accordingly he employed architects to frame it in wood and iron, so that it might be transported in safety, without any regard for the cost, so great was his desire. But the king was thwarted by its being done on the wall, and it remained with the Milanese. ${ }^{18}$

From a technical point of view, Louis XII's request was not only feasible but rooted in ancient tradition: Pliny, in his Natural History, described how in Sparta the Romans had a mural painting removed from a wall, and transferred to Rome in order to decorate an assembly-room..$^{19}$ In the Florentine Cathedral Santa Maria del Fiore, in 1398, the fresco of the Madonna and Child (about 1350-1375) which would become known as the Madonna dei Chierici, had been removed from the south lateral wall and transferred to a new tab-

15 On the French conquest of Milan see the historical studies by Léon Gabriel Pélissier and the more recent research by Henry Lemonnier and Stefano Meschini: Pélissier 1891; Pélissier 1896; Lemonnier 1982; Meschini 2004 and Meschini 2006; also see the symposium proceedings Balsamo (ed.) 1998 and Contamine/Guillaume (eds.) 1998.

16 Leonardi Vincii Vita, c 1527, published in Giovio (Maffei) 1999, 234.

17 Hollanda (Sedgwick Wohl) 2013, 75: "[...] the king of France wanted to remove from Milan to France a wall on which the Last Supper of Our Saviour was painted by the hand of Leonardo da Vinci".

18 Cf. Vasari (Milanesi) 1906-1910, vol. IV, 31 f.: "La nobiltà di questa pittura, sì per il componimento, sì per essere finita con una incomparabile diligenza, fece venir voglia al re di Francia di condurla nel regno; onde tentò per ogni via se ci fussi stato architetti, che con travate di legnami e di ferri l'avessino potuta armar di maniera, che ella si fosse condotta salva, senza considerare a spesa che vi si fusse potuta fare; tanto la desiderava. Ma l'esser fatta nel muro fece che sua Maestà se ne portò la voglia, ed ella si rimase a' Milanesi". English translation after Vasari (Dent) 1949-1950, vol. II, 162.

19 Pliny (Rackham/Jones) 1975, book 35, 173. 
ernacle chapel inside the church. ${ }^{20}$ In 1474, Piero della Francesca's Resurrection was transferred from one wall to another in the communal palace in Sansepolcro which attests to the fact that the technical knowledge for this kind of practice was available at the time. ${ }^{21}$ However, Louis XII's wish was not granted, possibly because of the imposing dimensions of Leonardo's mural.

The decision to leave the painting on the wall could have also been determined by the fact that it was already showing the first signs of deterioration. Instead of working in the traditional technique of buon fresco, which required rapid execution and therefore did not suit Leonardo's slow and thoughtful artistic approach, the Florentine master had experimented with a new artistic procedure by applying tempera colour mixed with an oily binding agent on a dry plaster base-coat covered with a layer of lead white. Because of this unconventional method and due to the humidity of the refectory's wall, the mural very soon began to display a network of cracks. The lifting of the pictorial layers resulted in the flaking of the paint. As early as 1517, Antonio de Beatis, secretary to cardinal Louis d'Aragon, observed the beginning of the mural's deterioration. ${ }^{22}$ Fifty years later, according to Vasari, it had become a macchia abbagliata, a glaring spot. ${ }^{23}$

For whatever reason the mural remained in situ, Giovio's account reveals the great fascination exerted by Leonardo's painting on Louis XII. This subsequently also affected members of his court: in the following years, many French dignitaries who settled or regularly stayed in Lombardy, commissioned Lombard painters to copy the masterpiece in Santa Maria delle Grazie.

\section{Copies of Leonardo's Last Supper commissioned by French nobles}

The first of these "French" copies of Leonardo's Last Supper is recorded in a contract dated 29 May 1503, in which Antonius de Torpinis, alias Antoine Turpin, appointed Bartolomeo Suardi, also known as Bramantino, ${ }^{24}$ to execute a copy of the painting. According to their agreement, the artist had one year to finish his work, which was to be painted on canvas provided by the purchaser, whose dimensions were unfortunately unspecified. During

20 In 1841, the fresco was moved to one of the chapels in the gallery of the church, where it is currently located. On the cult of the Madonna dei Chierici that, from December 1397, reportedly began to trigger miracles, see Poggi (Haines) 1988, vol. I, CVI-CXII, 200-205; 208 f.; Holmes 2013, 77-79 and 211, fig. 56. I warmly thank Prof. Megan Holmes for this information.

21 Fagnart 2013a, 113, n. 21.

22 Beatis (Hale) 1979, 182: "This [Leonardo's mural] is most excellent, though it is starting to deteriorate: whether because of the dampness of the wall or because of some other oversight, I do not know".

23 Vasari (Milanesi) 1909-1910, vol. VI, 491 (after Giorlamo da Carpi's life). According to the English translation, the mural "showed no more than a series of confused images" (Vasari [Dent] 1949-1950, vol. III, 317).

24 On Bramantino's activity see the two recent exhibition catalogues, exh. cat Milan 2012 and exh. cat. Lugano 2014, and the symposium proceedings Natale (ed.) 2017. 
that period Bramantino was to be guaranteed access to the refectory of Santa Maria delle Grazie; should the monks prevent access or trouble the artist, Turpin would intervene in his favour. Certainly, Antoine Turpin, designated in another document as "magnificus et generosus", ${ }^{25}$ was a powerful and influential figure who had enough means to ensure the monks' cooperation so that they would remain "taciti et contenti". ${ }^{26}$ The remuneration amounted to 100 golden scudi, equivalent to 400 lire imperiali, a considerable sum of money, which would have been needed to induce a painter of Bramantino's standing to accept the commission - even if or maybe precisely because it meant working in a style remarkably different from his own. ${ }^{27}$

Indeed, a well-established painter was chosen for this task of copying: after Leonardo and Bramante had left Milan, Bramantino was one of the most esteemed painters in the city. He received regular commissions from French governors and in particular from Louis of Luxembourg, Count of Ligny, who charged him with the decoration of his castle in Voghera in around 1502. ${ }^{28}$ The following year, Gian Giacomo Trivulzio, Marshal of France, requested Bramantino to draw the cartoons for a series of twelve tapestries representing the Months (Milan, Castello Sforzesco) and some years later he involved him in the construction of his funeral chapel in San Nazaro in Brolo. ${ }^{29}$ It is possible that Trivulzio, who acted as the governor of the duchy for only a few months, recommended Bramantino to Antoine Turpin. ${ }^{30}$

As for Antoine Turpin, few documents cast light on his private life or professional career. Lord of La Chaussée, he was notary and secretary of Louis XII. ${ }^{31}$ In May 1502 he was appointed chief treasurer and general collector of the ordinary and extraordinary finances of the duchy, a charge that he kept until his death in April 1505. ${ }^{32}$

Apart from the copy of the Last Supper, no other artistic commissions can be linked to Turpin and, unfortunately, Bramantino's work seems to be lost. However, we can assume that its visual qualities were quite similar to Leonardo's original. Indeed, the requirement of faithfulness to the original was made explicit in the contract, in which it is stressed twice that the copy had to be ad similitudinem to the painting in Santa Maria delle Grazie:

25 Sironi 1988,42 , doc. 3.

26 Sironi $1988,41$.

27 Shell/Sironi 1989, 105.

28 On 10 October 1499, Louis de Luxembourg received the fiefdom of Voghera from King Louis XII as a reward for his military exploits. A document dated 1503 (Shell 1995, 101, 240, doc. 65) attests that the artist required the total payment of 25 scudi for some unspecified paintings from Louis of Luxembourg. As this sum would be too scarce to cover the payment for the murals in Voghera, Bramantino probably executed other works for the Count of Ligny (cf. Paganin 2005; Paganin 2009).

29 On Trivulzio's artistic commissions, see Viganò 2017.

30 Shell/Sironi 1989, 105; Fagnart 2009, 155; Fagnart 2013a, 114 f.

31 Fagnart 2009, 155; Fagnart 2013a, 114.

32 Meschini 2004, 184-186. 
In primis quod dictus dominus Bertholomeus teneatur et obligates sit hinc ad festum pasce maioris resurrections domini nostri Ihesu Christi proxime guturum vel circha retrahere seu retrahi facere mensam duodecim apostolorum depinctam in refectorio monasterii seu ecclesie sancta Marie gratiarum mediolani syte extra portam vercelinam mediolani ad similitudinem dicte pictura, [...] Et resciduum predictus dominus Antonius teneatur solver totiens quotiens necesse et opus erit pro perfectione dicti operis. Et quod dictum opus inteligatur esse perfectum, modo habeat acta ad similitudinem dicte mense duodecim apostolorum [...] ad laudem duorum amicorum comunium comuniter et concorditer elegendorum per dictas partes aut per unam ex eis in contumatiam alterius. [author's italics]. ${ }^{33}$

In this contract, there is seemingly an ambiguity in the meaning of the noun perfectione as well as in the past participle perfectum: certainly, they both indicate that the painting had to be reproduced in its entirety; however, they also seem to include a notion of perfection in relation to the quality of the imitation of Leonardo's mural. Accordingly, the painting would be considered finished only if it managed to attain the requested degree of similarity to the original and at the same time to complete it where the model was already damaged. This nuance is fully supported by the successive use of similitudinem and, above all, by the explicit request that two friends in common, chosen by both the purchaser and the artist, had to judge the work. ${ }^{34}$ Bramantino's reputed artistic talents must have assured Antoine Turpin that his requests would be entirely satisfied and that his copy would be perfectly similar to Leonardo's original.

Three years later, Gabriel Gouffier, then Dean of the cathedral at Sens and designated as apostolic protonotary, appointed a former pupil of Leonardo, Marco d'Oggiono ${ }^{35}$, to produce a copy of the Cenacolo as reported in a contract dated 16 June 1506: ${ }^{36}$

\footnotetext{
Item che dicto magistro sia obligato in dicto termino a depingere uno cenacolo in tella largo braza x et alto braza v a similitudine di quello ch'è dipinto al monasterio de li Gratii di Millano, con uno frixo de oro fine in campo azurlo, de larchezia de mezo brazo con XIII ${ }^{\circ}$ medalie colorite de profete et sibilie con lo dicto l'oro et tuto di bon colori fini et azurlo vultramarino, ad laudem duorum magistrorum comuniter elligendorum; [...]. ${ }^{37}$
}

Marco d'Oggiono had to complete both works within three years, receiving in return a series of payments totalling 275 scudi (1200 lire imperiali) which is considered to be a very generous remuneration. ${ }^{38}$ The copy was to be about three-quarters the size of the original and had to resemble it closely. Again, it is specified that the work had to be "a si-

33 1503, May 29, Milan, Archivio di Stato, Fondo Notarile, not. Francesco Moriggi, fol. 6190. The document is fully transcribed in Sironi 1988, 41; Shell/Sironi 1989, 109-111; Shell 1995, 253 f., doc. 94.

34 Many thanks to Yannick Zannetti for his valuable translation.

35 On Marco d'Oggiono see Sedini 1989, in particular on his copy see cat. 28, 68-72 (in which previous bibliography is quoted).

36 Shell/Sironi 1989, 105-107. In 1506, Gabriel Gouffier passed through Milan on the way to Rome to settle chapter disputes, and there he commissioned Marco d'Oggiono to copy the Last Supper.

37 1506, June 16, Milan, Archivio di Stato, Fondo Notarile, not. Nicolo Draghi, fol. 3019 (see Shell/ Sironi 1989, 111-115; Shell 1995, 254-255, doc. 95).

38 Shell/Sironi 1989, $106 \mathrm{f}$. 
militudine" to the original and that two friends in common were requested to approve it. However, a notion of perfection as it had been mentioned in Turpin's contract is missing. On the one hand, the painting, which is today kept in the Musée national de la Renaissance in Écouen (plate X), perfectly demonstrates the degree of the painter's faithfulness to the subject: the apostles' gestures, movements and astonished appearance as well as their costumes and the table settings are replicated exactly. Even the landscape, perceived through the three openings in the background, is characterised by a similar verdant-blue mountainous view. On the other hand, the spatial structure and its perspective unconvincingly differ from the original: ${ }^{39}$ Marco d'Oggiono conceived an environment articulated by Corinthian pillars and by door openings to the left and right hand sides, instead of reproducing Leonardo's original tapestries which hang on the wall. Additionally, according to the contract, the painting had to be framed with a frieze in gold on a blue background and decorated with fourteen coloured medallions of prophets and sibyls. This ornamentation is unfortunately lost today, but it undoubtedly pointed to the patron's appreciation of antiquity as well as of the fresco as a precious object (mediated by means of the copy), that should be illusionistically framed and enshrined. At the same time, the vocabulary of the framing and the pilaster setting also seems to add a humanistic dimension to this kind of sacred picture, possibly to better suit the decoration of a private dwelling. Nevertheless, Oggiono's accuracy in copying the main scene of the Lord's Last Supper - which, as briefly noted at the beginning of this text, constituted the most admired element by contemporaries - guaranteed that Leonardo's model could be fully recognised.

When the canvas was restored towards the end of the $1970 \mathrm{~s}$, four coats of arms were discovered on the table trestles. These blazons were later identified by Thierry Crépin-Leblond as the heraldry of Gabriel Gouffier, which links the copy still closer to the contract mentioned above. ${ }^{40}$ As Canon and subsequently Dean of Sens Cathedral from 1502 to 1529, Gabriel Gouffier seems to fall perfectly into the category of the new elite of important and powerful members of the French court who famously exploited art, and in particular the recently discovered art of Italy, as a means to display their wealth and to gain political influence. ${ }^{41}$ Indeed, he was appointed dean in 1504 thanks to the special permission granted by Cardinal Georges d'Amboise, prime minister and main counsellor of Louis XII, and towards the end of his life he was the vicar general of Antoine Durpat, Archbishop of Sens and Chancellor of France. ${ }^{42}$ Both Georges d'Amboise and Antoine Durpat were dominant figures within the French kingdom. ${ }^{43}$ They obtained

39 Crépin-Leblond 2000, 61.

40 Crépin-Leblond 2000, 61.

41 Blunt 1983, 16-38.

42 Nassieu Maupas 2011, $257 \mathrm{f}$.

43 On Georges d'Amboise see the recent publication by Dumont/Fagnart (eds.) 2013, while on Antoine Duprat see the older, but still comprehensive, study by Buisson 1935. 
financial advantages and political influence thanks to their privileged relationship with Louis XII and, in part, with Francis I. Gabriel Gouffier's artistic commissions, in particular the rose window for Sens Cathedral, the panelling and the stained-glass for his brother's funerary chapel as well as the restoration works of the Enfonchure priory, where he was appointed abbé commendataire, reveal his fondness for Italian art. ${ }^{44}$ Thus, the replica of Leonardo's Last Supper fits perfectly with Gouffier's pronounced taste for antiquity and is fully in accordance with the artistic vogue of the time. Just a few decades later, his copy was acquired by Anne of Montmorency, marshal of France, who from approximately 1538 to 1555 undertook the construction of Écouen Castle, possibly in order to mark his appointment as constable of the kingdom. This prestigious provenance undoubtedly attests to the preciousness of Gouffier's copy and of its being coveted by other French dignitaries. ${ }^{45}$

A further copy of the Cenacolo is mentioned in two inventories of Gaillon Castle: the first, dated 13 November 1540, lists the belongings of Cardinal George II d'Amboise; the second, drafted a few months after his death, is dated 31 August $1550 .{ }^{46}$ According to the first record, the painting was made on canvas and brought from Milan "by the late His Grace". It can be inferred that "His Grace" was Cardinal Georges I d'Amboise, uncle of the above-mentioned Georges II. ${ }^{47}$ This powerful cardinal, who twice failed to be elected Pope and who was commonly considered to be the true King of France - Ipse est vere rex Franciae ${ }^{48}$ - took an active part in the Italian wars and in the reorganisation of the government of the duchy; most notably after the Milanese revolt in January 1500 and the temporary return of Ludovico Sforza. In addition to two triumphant entrances of the French into the city in October 1499 and in April 1500, Georges I d'Amboise was

44 Nassieu Maupas 2011, $257 \mathrm{f}$.

45 There is a gap of about one century in the painting's provenance history - between its commission in 1506 and the first evidence of its actual existence in 1606, when the work hung in the chapel of Écouen Castle as mentioned in a letter by Nicolas Fabri de Peiresc (Crépin-Leblond 2000, 61 and 62, n. 8). Many hypotheses have been formulated to explain how Gouffier's painting ended up in the hands of Anne de Montmorency (Roman 1883, 64 f.; Béguin 1985, 109, n. 25; Crépin-Leblond 2000, 61 f.; Fagnart 2002, 35 f.; Fagnart 2009, 158). It appears, however, that these propositions, which were based on the traditional belief that Gabriel Gouffier was the illegitimate son of Guillaume Gouffier, Lord of Bonnivet, a French admiral, are no longer accepted following Nassieu Maupas' recent study (Nassieu Maupas 2011). Casting light on Gabriel Gouffier's origins, the author fully demonstrated that he actually belonged to a family native to the Auvergne region. In the 1530s his copy of the Last Supper probably passed into the hands of the canons of Notre-Dame Cathedral in Paris. According to the chapter register dated 1534, Clergyman Guillaume Gouffier - not to be confused with the French admiral mentioned above - promised to offer a copy of the Last Supper to the Cathedral. In all likelihood, Guillaume Gouffier received the painting from Gabriel Gouffier, with whom he was related; however, their degree of kinship has not yet been fully determined. It is still unclear how the canvas was finally acquired by Anne of Montmorency.

46 The first inventory is conserved in Paris (Bnf ms. Fr. 26533, fol. 300r - 313r) while the second is kept in Rouen (ADSM, G 868). See the last publication on the Gaillon's inventories: Fagnart 2013b, part. 172, 179-181.

47 Fagnart 2009, 158; Fagnart 2013a, 116; Fagnart 2013b, 179.

48 Souchal 1976, 578. 
witnessed on several occasions in Milan where he probably commissioned the above-mentioned copy from Andrea Solario, one of Leonardo's pupils. ${ }^{49}$ Undoubtedly, he must have seen Leonardo's mural in Santa Maria delle Grazie. He may also have seen the fresco by Andrea Solario - a copy of the Last Supper - in the refectory of the Hieronymite monastery in Castellazzo, in the province of Milan. ${ }^{50}$ This may have convinced him of Solario's artistic and imitative skills and encouraged him to appoint the painter to produce yet another copy of this work. ${ }^{51}$

The Gaillon inventory of 1540 reports that the apostles were "large figures", which leads us to assume that the dimensions of the copy must have been remarkable, probably similar to Leonardo's mural. ${ }^{52}$ We do not know where the canvas was originally hung, however, according to the inventory of 1550, the painting was set in the "big gallery", next to sixteen wooden desks displaying the cardinal's book collection. ${ }^{53}$ This gallery must have been in a prestigious location, allowing privileged visitors of the castle to admire the Last Supper set among the precious manuscripts and printed French and Italian books collected by Cardinal Georges d'Amboise during his lifetime. ${ }^{54}$

The final example of a faithful copy after Leonardo's Last Supper explored here is a tapestry today preserved in the Vatican Museums (fig. 2). ${ }^{55}$ Its borders are decorated with grotesque and heraldic patterns which leave no doubt about the illustrious identity of its patrons: Francis d'Angoulême, later King of France (1515-1547), and his mother Louise of Savoy. ${ }^{56}$ The salamanders depicted in the frame are not crowned, indicating that the tapestry was ordered before Francis' accession to the throne in January 1515, but probably after 1505. In fact, as early as 1498 Francis d'Angoulême, together with his mother, had been invited to reside at the court in Blois, but it was in 1505 that King Louis XII entrusted cardinal Georges d'Amboise with the responsibility for and education of the young count who, at the time, was aged eleven. ${ }^{57}$ This closeness probably gave Francis d'Angoulême and Louise of Savoy the opportunity to admire the cardinal's painted copy of the Last Supper in Gaillon and, even though they had not seen Leonardo's original,

49 Fagnart 2009, 158, n. 39; Fagnart 2013a, 116, n. 29; Fagnart 2013b, 179, n. 40.

50 According to Steinberg 1973, 409 f., the Castellazzo fresco, destroyed during the Second World War, measured $3.38 \times 6.74$ meters.

51 Brown 1987, 204. In 1507, Andrea Solario accepted the cardinal's proposal to decorate the chapel of his castle in Gaillon. The artist stayed in France, working for Georges d'Amboise, until the death of the latter in 1510 (Béguin 1985; Brown 1987, 151-216; Béguin 1999).

52 Fagnart 2009, 158.

53 Fagnart 2013b, 179.

54 Toscano 2009; Dumont/Fagnart (eds.) 2013, 131-222.

55 Möller 1952, 129-134; Fagnart 2001; Fagnart 2009, 159-164; Fagnart 2013a, 165 f.

56 The cord forming a knot is the emblem of the Savoy Family while the pair of wings and the monogram L-O-S-E, in the two lower angles, indicate in particular Louise. The salamander in the middle of the vertical edges and the emblems on the upper coroners of the tapestry point to Francis d'Angoulême (see Fagnart 2001, 166 f.; Fagnart 2009, 159 f.; Fagnart 2013a, 165 f.).

57 As the administration of the kingdom was very demanding, the cardinal soon entrusted Artus Gouffier, Lord of Boisy, with this charge (Fournial 1996, 25; Fagnart 2001, 166). 


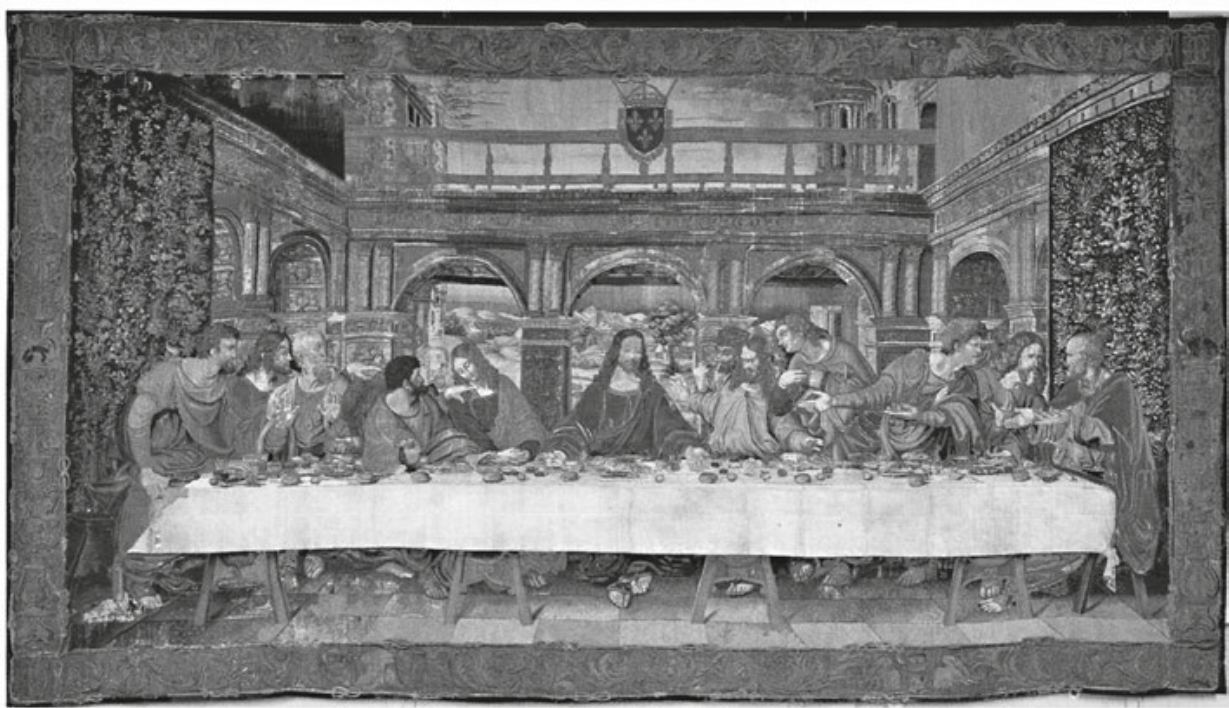

2 Manufacture of the Southern Netherlands, The Last Supper with the coat of arms of Francis d'Angulême and of Louise de Savoie, 1508-1514, tapestry, $490 \times 915 \mathrm{~cm}$, Vatican city, Pinacoteca dei Musei Vaticani

they held the picture in such high esteem that they considered it sufficiently important to commission their own copy of it. In addition, as will be developed hereunder, the fascination exerted by the painting in Santa Maria delle Grazie on the French invaders is also to be attributed to its association with the previous ruler of Milan, Ludovico il Moro. Certainly, Francis d'Angoulême and Louise of Savoy did not ignore the political dimension of the Last Supper.

Weaved in a workshop located in the Southern Netherlands, probably using the cartoons drawn by Bramantino, ${ }^{58}$ or perhaps even the Florentine master himself, ${ }^{59}$ the tapestry faithfully reproduces - at full scale - the table, the still life and the disciples' ges-

58 This attribution, suggested by Pietro C. Marani (Fangart 2009, 163), is based on the typology of the grotesques decorating the borders of the tapestry, which clearly refers to the ornaments of the Domus Aurea in Rome. According to Marani, only a "leonardesque" who had visited Rome could have realized the cartoons of Vatican tapestry of the Last Supper. Bramantino seems to be the best candidate, considering his previous engagements for the French, in particular his copying the Last Supper for Antoine Turpin, and the fact that he worked for the Pope Julius II in Rome from 1508-1509.

59 Sforza Galitzia postulates that Leonardo drew the cartoons, which were then completed by a Flemish cartoonist, and that the tapestry was woven after 1507. Moreover, because of some handwritten notes in the Codices Madrid I, Atlanticus and Forster II, she hypothesizes that the Florentine master provided the Royal Family with studies on technological improvements to the loom (Sforza Galitzia $2009,45-53,71)$. 
tures of Leonardo's Last Supper. However, instead of an austere refectory, the environment in which the meal takes place is a rich Italian Renaissance loggia with three archways opening onto a landscape. On the balustrade appears the shield of the Kings of France, surrounded by the necklace of the order of Saint-Michel. ${ }^{60}$ Again, this more courtly setting certainly satisfied the refined taste of Francis d'Angoulême and his mother and was undoubtedly more appropriate for the decoration of a castle wall than that of a refectory. ${ }^{61}$ As for Marco d'Oggiono's copy, the differing environment conceived in the Vatican tapestry does not preclude the recognition of the main scene as being Leonardo's Last Supper. The composition, with the lively interaction of its figures forms the work of art, and the similarity requested is a similarity of figural composition, not of architectural setting. The notion of a copy replicating the whole picture plane, which is common nowadays, was apparently not shared in these two cases. Thus, faithfulness here applies to the istoria rather than to the overall appearance of the painting.

Many other "French" copies of Leonardo's mural were executed in the first decades of the $16^{\text {th }}$ century, ${ }^{62}$ for example the painting today kept in Troyes Cathedral, made by a local painter at the request of Guillaume Petit, Bishop of Troyes between 1519 and 1527, the copy in Saint-Germain l'Auxerrois in Paris (around 1520), attributed to a follower of Cesare Magni and probably commissioned by Jean V Burdelot, attorney general of the Senate in Milan, as well as the canvas in Tongerlo Abbey, ${ }^{63}$ which was most likely executed in the workshop of Giampietrino around 1520 (fig. 3). ${ }^{64}$ In 1545, Abbot Arnold Streyters purchased the Tongerlo painting for 450 florins in Antwerp from the heirs of Jean le Grand, a native of France, and a document dated prior to 1615 reports that this painting was undertaken following the order of "a French king who captured Milan". ${ }^{65}$ This is commonly considered, among all known surviving copies, to be one of the most exact and faithful reproductions of Leonardo's Last Supper. Apart from a few changes, such as the slight shifting of the figures to the left, seen for example in Christ's head, the lower placement of the table, the decoration of the tapestries or the embroidery of the ta-

60 This emblem was added in 1533, when the tapestry was offered by Francis I to Pope Clemente VII on the occasion of the wedding of Henry d'Orléans (later Henry II) - the pope's nephew - to Catherine de' Medici (Fagnart 2001, 167 f.; Sforza Galitzia 2009, 63-69).

61 In 1533 the tapestry is documented in an inventory of Blois Castle, but its exact location is unknown (Fagnart 2001, 167 f.).

62 Fagnart 2009, 167-172.

63 Möller 1952; Marijnissen 1959; Fagnart 2005.

64 Fagnart notes that this canvas shares strong similarities - in the proportions, the spacing, and the positioning of certain elements - with the painted copy today kept in the Royal Academy of Arts in London, which was realised around 1515 by Giovan Pietro Rizzoli, also called Giampietrino (Shell/ Brown/Brambilla Barcilon 1988; Marani 2001, $190 \mathrm{f}$.). Thus, the two copies must have been executed in the same workshop using the same tracing paper or pouncing pattern (Fagnart 2005, 208210).

65 Marijnissen 1959,15, 54. It is difficult to determine whether this indication is reliable or not, but a royal commission would certainly not be unlikely. If confirmed, it would then refer to Francis I who reconquered the Duchy of Milan in 1515 - as the canvas is dated around 1520. 


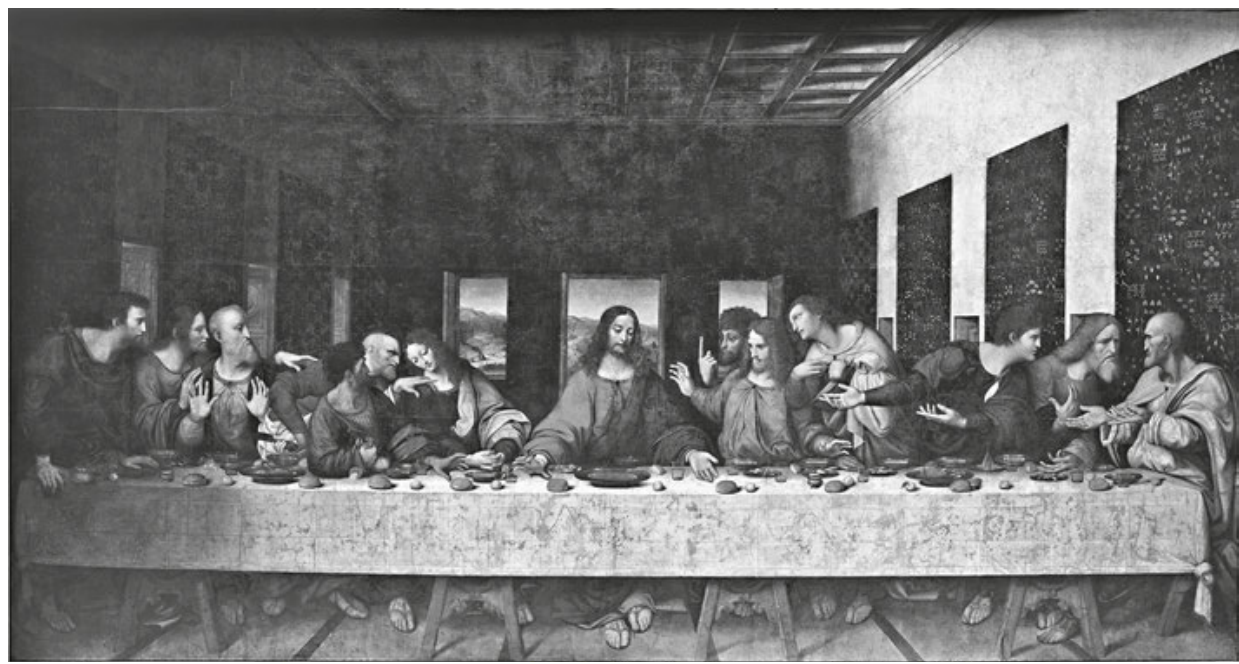

3 Giampietrino's workshop, The Last Supper, c 1520, oil on canvas, $424 \times 802 \mathrm{~cm}$, Tongerlo, Da Vinci-Museum

blecloth, it perfectly reproduces the scene as depicted by Leonardo. Likewise, the colours and the use of chiaroscuro are thought to be accurate, though this is hard to judge based upon the current state of the original. ${ }^{66}$

\section{Reasons for commissioning copies of Leonardo's mural}

Considering the already poor state of preservation of Leonardo's Last Supper mural in the $16^{\text {th }}$ century, it is not surprising that faithful replicas were commissioned to keep a visual memory of a masterpiece which was inescapably decaying. The fact that Andrea Solario's fresco in Castellazzo was taken off the wall in 1832 - as the monastery was due to be demolished - and, in 1891, was placed in the refectory of Santa Maria delle Grazie next to Leonardo's original, supports this assumption, at least for the $19^{\text {th }}$ century. ${ }^{67}$ Certainly, the proximity of the two paintings facilitated the interpretation and appreciation of the masterpiece, both by visitors to the monastery and by artists copying the mural (fig. 4).

As stressed by Laure Fagnart, the purpose of such artistic commissions was to have a "souvenir reproduction" of the most celebrated and fashionable masterpiece, not only in Lombardy, but in the whole of Italy at the time. Indeed, for French dignitaries this was

66 Fagnart 2005, 208-210.

67 Steinberg 1973, $409 \mathrm{f}$. After twenty-five years, the painting was moved from the refectory to the library of Santa Maria delle Grazie, where the bombing of 1943 destroyed it. 
4 Interior of the refectory in Santa Maria delle Grazie with Andrea Solario's painting next to Leonardo's mural, 1875-1910

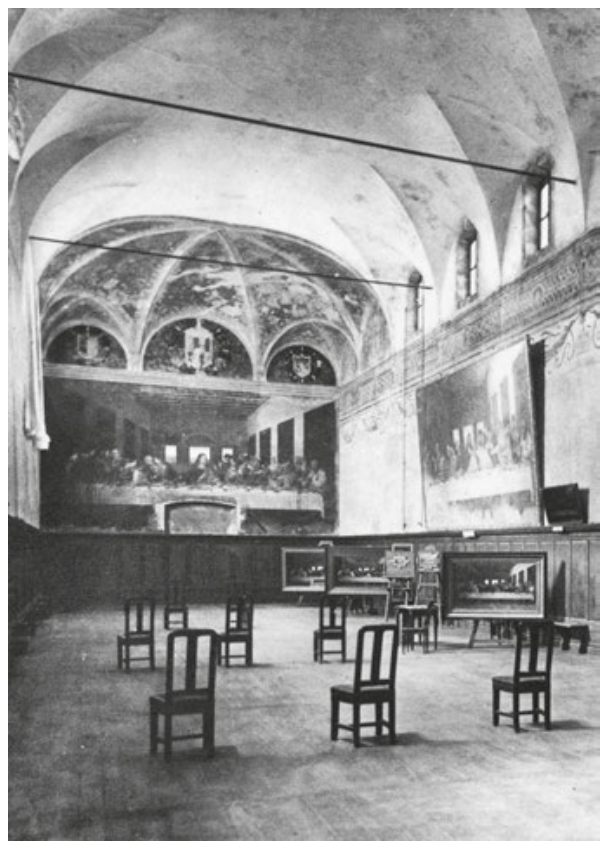

undoubtedly both prestigious and a method of displaying refined artistic taste, not to mention their wealth. The artists they engaged, such as Bramantino and Marco d'Oggiono were correspondingly well rewarded financially. Commissioning copies was certainly also a method of emulating and promoting their king's artistic taste and of demonstrating their deference to him. ${ }^{68}$

However, this article proposes that, in addition, these commissions were also driven by strong political motivations. Since his accession to the throne of France in 1498 Louis XII had officially claimed possession of the throne of the Duchy of Milan. This desire was perfectly in line with the Mediterranean foreign policy of his predecessors, who had wanted to extend the boundaries of the kingdom and increase its influence. ${ }^{69}$ Louis XII's claim to Milan was founded upon political and dynastic ambitions coupled with personal motivations. ${ }^{70}$ This directly concerned the current ruler of the city, Ludovico Sforza.

68 Fagnart 2002, 40; Fagnart 2013a, 122.

69 Charles VIII, when aiming to conquer Constantinople and eager to make war on the Turks, launched the Italian wars in 1494-1495 with an expedition to the Kingdom of Naples, whose throne he aspired to on the basis of his Angevin rights.

70 Péllissier 1896, vol. I, 30-101. On the French conquest and domination of the Duchy of Milan see also Contamine/Guillaume (eds.) 1998. 
Firstly, the Duke of Milan was, at least in Louis XII's opinion, acquiring too much power on an international scale and openly adopting anti-French policies. In particular in 1495, he joined the Holy League or League of Venice - a coalition formed by several opponents of French hegemony in Italy as a direct response to the Italian military campaign of Charles VIII. By entering this alliance, Ludovico Sforza openly rejected the traditional friendship linking the Duchy of Milan to French territories which had been consolidated by numerous matrimonial unions. ${ }^{71}$

Secondly, Louis XII's grandmother, Valentina Visconti, had been the daughter of the first Duke of Milan, Gian Galeazzo Visconti. In 1389, on the occasion of her marriage with Louis of Valois, Duke of Orléans, it was stipulated that, in the event of the extinction of her brothers' male heirs, she would inherit the Visconti dominions. Her first halfbrother Gian Maria was assassinated in 1412 aged 24 while her second half-brother, Filippo Maria, ruled the duchy until he died in 1447 without legitimate offspring. The Ambrosiana Republic was then established until Francesco Sforza finally seized control of the duchy in 1450, claiming his rights due to his marriage to Bianca, natural daughter and only heir of Filippo Maria Visconti. Yet, according to Louis XII, the Sforza dynasty was not the legitimate ruler of the duchy; instead he firmly believed the duchy was a legal part of his own family heritage.

Finally, during the military campaign of his uncle Charles VIII, the young Louis, at the time still Duke of Orléans, was comprehensively beaten by the troops of Ludovico Sforza, who besieged his forces in Novara and again in Asti. Defeat naturally raised a desire for personal revenge in the Duke of Orléans, who already aspired to dethrone his Lombard enemy. Additionally, Ludovico Sforza had obtained the imperial privilege and the title of Duke of Milan from the Emperor Maximilian for a fee of 100,000 ducats, just before the death of his nephew Gian Galeazzo Sforza in 1494. This act was of course considered an open provocation to the future King of France.

During that time, Ludovico Sforza, proudly conscious of his newly won political power and anxious to give visible expression to his position, chose the compound of the monastery of Santa Maria delle Grazie as his court church and family mausoleum. ${ }^{72}$

71 In 1350, Galeazzo II Visconti, Lord of Milan, married Bianca, daughter of Aimone, Count of Savoy. Ten years later, in 1360, they arranged the union of their son Gian Galeazzo Visconti - who was appointed Duke of Milan in 1395 - with Isabella, daughter of John the Good, King of France. Their daughter, Valentina Visconti, married Louis of Valois, Duke of Orléans in 1389. In 1428, Filippo Maria, third Duke of Milan, married his second wife Marie of Savoy, daughter of Duke Amadeus VIII of Savoy. In 1468, the alliance with the House of Savoy was renewed by the marriage of Galeazzo Maria Sforza with Bona of Savoy.

72 It is not clear whether Ludovico Sforza intended to use Santa Maria delle Grazie as a family burial place from the very beginning of the works. However, in 1497, at the sudden death of his beloved wife, Beatrice d'Este, he commissioned a mausoleum from Cristoforo Solari who sculpted a marble tomb with the recumbent statues of the Duke and the Duchess, which was placed in the choir of the church. After the defeat of Ludovico Sforza and his death in 1508, the mausoleum was dismembered and dispersed. Only the cover with the two statues is today kept in the Certosa of Pavia. 
Consequently, he engaged the two greatest artists currently in Milan, Donato Bramante and Leonardo da Vinci, to create an architectural and artistic programme celebrating the Sforza dynasty as well as himself. ${ }^{73}$ Ludovico's project included the enlargement of the refectory, which was decorated by Leonardo between 1494 and 1498. Above the Last Supper, the Florentine master painted the Sforza coats of arms in three majestic lunettes above the mural (fig. 1). The lunette in the middle celebrates Ludovico Sforza and his wife Beatrice d'Este as the Duke and Duchess of Milan, while the two lunettes on the sides pay tribute to their progeny. To the left, their eldest son Massimiliano is represented by his coat of arms as the earl of Angera and of Pavia, whilst the lunette on the right hand side probably represents Francesco II with his coat of arms as Duke of Bari. ${ }^{74}$ Rediscovered in 1854 under four coats of plaster, these coats of arms were, according to Marani, painted over probably immediately after the fall of Ludovico Sforza in 1499, "the motive being what amounted to a damnatio memoriae that would remove all Sforza names and replace them, in all likelihood, with those of the King of France". ${ }^{75}$

In consideration of all these historical, political, and artistic elements, we can safely conclude that the acquisition of a copy of the Last Supper by French dignitaries would have been perceived as an act of appropriation and a way to legitimise the French conquest of the Duchy of Milan. Ludovico Sforza had given the commission to decorate Santa Maria delle Grazie's refectory to Leonardo, who was already proclaimed as the new Apelles during his lifetime. ${ }^{76}$ The Duke had also requested his own coat of arms and those of his sons to be painted above one of the greatest Lombard masterpieces - also commonly considered a "divine" and "miraculous" image - as a manifest celebration of the Sforza dynasty. ${ }^{77}$ This dynasty in turn had, according to Louis XII, seized control of the government of Milan by usurping the Visconti's throne. Furthermore, Ludovico Sforza had assumed the government of the duchy by depriving his young nephew Gian Galeazzo Sforza of the throne and, in addition to this double usurpation, he had bought the official acknowledgement of his title from the Emperor Maximilian. Hence, Louis XII's plausible request to erase the Sforza's emblems in the lunettes and to remove the Last Supper from the wall in order to bring it to France must be read as a clear assertion that the famous masterpiece rightfully belonged to him and that, being the legitimate Duke of Milan, he fundamentally owned Lombardy. By appointing the best Milanese

73 Beltrami [1925?], 37 f.; on the history of the church's construction see Marani/Cecchi/Mulazzani 1999, 49-81 and Buganza/Rainini (ed.) 2017, in particular section III.

74 Contrary to the other members of the family, his name does not appear (see Marani/Cecchi/Mulazzani 1999, 33, 44, n. 17).

75 Brambilla Barcilon/Marani 1990, 9; Marani/Cecchi/Mulazzani 1999, 34.

76 The poet at the court of Ludovico Sforza, Bernardo Bellincioni, was the first to report that "[Ludovico il Moro] Da Fiorenza un Apelle ha qui condotto" (Bossi 1810, 244).

77 In addition, Ludovico Sforza asked Leonardo to complete Donato Montorfano's Crucifixion, painted in 1497 on the wall facing the Last Supper, with his portrait and that of his wife and children (Malaguzzi-Valeri 1915, 536 f.). 
artists to paint a copy of Leonardo's mural, the members of his court, sharing the king's political ideas and his claim to the duchy, wished to express their adherence to his rule and to show him their political support. Also, they may have intended to justify his military incursion into Lombardy. For this purpose, it was hence fundamental that the copy be faithful enough to Leonardo's mural because it had to embody, as it were, a war trophy, and thus present a surrogate for the original. Indeed, the peculiar iconographical episode chosen by the Florentine master and the representation of the disciples' attitudes and astonishment are always carefully reproduced by the copyists. Thus, even though the setting might sometimes be very dissimilar, as in the Vatican tapestry, the main scene is always undoubtedly recognisable as the one painted by Leonardo in Santa Maria delle Grazie. Hence, even if from today's point of view, the changes made to adapt the copies to their private courtly settings do not comply with our expectations of faithful copies, the recognition of the specific model (as opposed to just any depiction of a Last Supper) remained guaranteed. Finally, the representation of nobles' coats of arms, whether in the holy scene or in the frame, also contribute to this act of appropriation, as a way of taking possession of Leonardo's artwork and what it represented both artistically and politically.

\section{Bibliography}

Alberti, Leon Battista: Della pittura, ed. by L. Mallé, Florence 1950.

Antonelli, Rosalba: Gli studi preparatori della copia del Cenacolo di Giuseppe Bossi allo Schlossmuseum di Weimar, in: Raccolta Vinciana, 26.1995, 287-327.

Balsamo, Jean (ed.): Passer les Monts. Français en Italie - l'Italie en France (1494-1525). X ${ }^{e}$ colloque de la Société française d'étude du Seizième Siècle, Paris 1998.

Bandello, Matteo: Le Novelle [1554], ed. by Delmo Maestri, Alessandria 1992, vol. I, novella LVIII, 513-517.

Beatis, Antonio de: The Travel Journal of Antonio de Beatis. Germany, Switzerland, the Low Countries, France and Italy, 1517-1518, ed. by John Rigby Hale, London 1979.

Béguin, Sylvie: Andrea Solario en France, Musée du Louvre (Les dossiers du Département des Peintures, 31), Paris 1985.

Béguin, Sylvie: Andrea Solario en France, in: Léonard de Vinci entre France et Italie: "miroir profond et sombre", Actes du colloque international de l'Université de Caen 1996, ed. by Silvia Fabrizio-Costa and Jean-Pierre Le Goff, Caen 1999, 81-98.

Beltrami, Luca: La chiesa di S. Maria delle Grazie, Firenze [1925?].

Bertoglio Pisani, Napoleone: Il Cenacolo di Leonardo da Vinci e le sue copie, Pistoia 1907.

Blunt, Anthony: Art et architecture en France. 1500-1700, Paris 1983.

Bossi, Giuseppe: Del Cenacolo di Leonardo da Vinci, Milan 1810.

Brambilla Barcilon, Pinin / Marani, C. Pietro: Le lunette di Leonardo nel refettorio delle Grazie, Milan 1990.

Brown, David Alan: Andrea Solario, Milan 1987.

Buganza, Stefania / Rainini, Marco (eds.): Il convento di Santa Maria delle Grazie a Milano. Una storia dalla fondazione a metà del Cinquecento, Atti del convegno di studi Milano 2014 (Memorie domenicane, nuova serie, 47, 2016), Florence 2017.

Buisson, Albert: Le chancelier Antoine Duprat, Paris 1935.

Contamine, Philippe / Guillaume, Jean (eds.): Louis XII en Milanais. Guerre et politique, art et culture, XLIe colloque international d'études humanistes 1998, Paris/Genève 2003. 
Crépin-Leblond, Thierry: L'origine de la copie de la Cène de Léonard par Marco d'Oggiono à Ecouen, in: Revue de l'art, 130.2000 (4), 60-62.

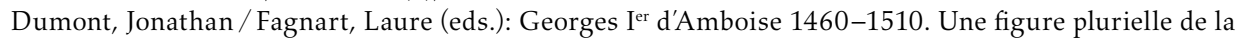
Renaissance, Actes du colloque international Université de Liège 2010, Rennes 2013.

Exh. cat. Bramantino. L'arte nuova del Rinascimento lombardo (Lugano, Museo Cantonale d'Arte 2014/2015), ed. by Mauro Natale, Milan 2014.

Exh. cat. Bramantino a Milano (Milan, Castello Sforzesco 2012), ed. by Giovanni Agosti, Jacopo Stoppa and Marco Tanzi, Milan 2012.

Exh. cat. Il Genio e le Passioni. Leonardo e il Cenacolo. Precedenti, innovazioni, riflessi di un capolavoro (Milan, Palazzo Reale 2001), ed. by Piero C. Marani, Milan 2001.

Exh. cat. Leonardo's Last Supper: Precedents and Reflections (Washington, National Gallery of Art 1983/1984), ed. by David Alan Brown, Washington 1983.

Exh. cat. Von Leonardo fasziniert. Giuseppe Bossi and Weimar (Weimar, Schiller-Museum 2016), ed. by Hermann Mildenberger and Serena Zaraboni, Dresden 2016.

Fagnart, Laure: L'arazzo con le insegne di Francesco d'Angoulême e di Luisa di Savoia, conservato nella Pinacoteca dei Musei Vaticani. Alcune ipotesi sull'origine lombarda del cartone, in: exh. cat. Milan 2001, 165-171.

Fagnart, Laure: L'engouement pour la Cène de Léonard de Vinci à la cour de France sous les règnes de Louis XII et de François I ${ }^{\text {er }}$, in: Les amis du château et des musées de Blois, 33.2002 (December), 33-40.

Fagnart, Laure: La copie de la Cène de Léonard de Vinci conservée à l'abbaye de Tongerlo, in: Bulletin de la Classe des Beaux-Arts de l'Académie royale de Belgique, 16.2005, 6 ${ }^{\text {ème }}$ série, 193-210.

Fagnart, Laure: Léonard de Vinci en France. Collections et collectionneurs ( $\mathrm{XV}^{\mathrm{e}}-\mathrm{XVII}^{\mathrm{e}}$ siècles), Rome 2009.

Fagnart, Laure: "Le roi Louis, en admiration devant le repas du Christ à Milan". Les Français et la Cène de Léonard de Vinci, in: Le Duché de Milan et les commanditaires français (1499-1521), ed. by Frédéric Elsig and Mauro Natale, Rome 2013, 107-126. [Fagnart 2013a]

Fagnart, Laure: Les biens meubles du château de Gaillon, in Dumont/Fagnart (eds.) 2013, 169-187. [Fagnart 2013b]

Fournial, Étienne: Monsieur de Boisy, Grand Maître de France sous François I ${ }^{\text {er }}$, Lyon 1996.

Giovio, Paolo: Leonardi Vincii Vitae, in: Paolo Giovio. Scritti d'arte: Lessico ed ecfrasi, ed. by Sonia Maffei, Pisa 1999, 234-245.

Hautecoeur, Louis: L'italianisme avant 1525, in: Histoire de l'Architecture classique en France, vol. I: La Première Renaissance (1495 à 1535-1540), Paris 1963, 97-216.

Hoerth, Otto: Das Abendmahl des Leonardo da Vinci. Ein Beitrag zur Frage seiner künstlerischen Rekonstruktion, Leipzig 1907.

Hollanda, Francisco de: On Antique Painting [1548], trans. by Alice Sedgwick Wohl, Pennsylvania 2013.

Holmes, Megan: The Miraculous Image in Renaissance Florence, London/New Haven 2013.

Horst, Carl: L'Ultima Cena di Leonardo nel riflesso delle copie e delle imitazioni, in: Raccolta Vinciana, 14.1930-1934, 118-200.

Lemonnier, Henry: Charles VIII, Louis XII, François Ier et les guerres d'Italie (1492-1547), Paris 1982.

Malaguzzi Valeri, Francesco: La corte di Ludovico il Moro. II. Bramante e Leonardo da Vinci, Milan 1915, 486-557.

Marani, C. Pietro / Cecchi, Roberto/Mulazzani, Germano: Il Cenacolo. Guide du réfectoire et de Sainte-Marie-des-Grâces, Milan 1999.

Marijnissen, Roger Hendrik: Het da Vinci-doek van de Abdij van Tongerlo, Tongerlo 1959.

Menu, Michel (ed): La pratique technique de Léonard de Vinci. Peintures, dessins et influence, Actes du colloque de la National Gallery de Londres 2012, Paris 2014.

Meschini, Stefano: Luigi XII duca di Milano. Gli uomini e le istituzioni del primo dominio francese, 1499-1512, Milan 2004.

Meschini, Stefano: La Francia nel ducato di Milano: la politica di Luigi XII (1499-1512), Milan 2006.

Möller, Emil: Das Abendmahl des Lionardo da Vinci, Baden-Baden, 1952. 
Nassieu Maupas, Audrey: Des mécènes méconnus. Gabriel Gouffier, doyen de Sens, et sa famille, in: Peindre en France à la Renaissance, vol. I: Les courants stylistiques au temps de Louis XII et de François Ier, ed. by Frédéric Elsig, Cinisello Balsamo 2011, 255-265.

Natale, Mauro (ed.): Bramantino e le arti nella Lombardia francese (1499-1525), Milan 2017.

Paganin, Maria Luisa: Un'impresa decifrata: il conte di Ligny committente di Bramantino a Voghera, in Prospettiva, 2005/2006 (119/120), 95-97.

Paganin, Maria Luisa: Una insolita iconografia in un affresco del castello di Voghera. Maria e il Bambino Gesù coperto di piaghe, in: Prospettiva, 2009 (134/135), 128-140.

Pélissier, Léon Gabriel: Documents pour l'histoire de la domination française dans le Milanais, 1499-1513, Toulouse 1891.

Pélissier, Léon-Gabriel: Louis XII et Ludovic Sforza (8 avril 1498-23 juillet 1500), 3 vols., Paris 1896.

Pliny the Elder: Natural History, transl. by H. Rackham and W.H.S. Jones, London 1975.

Poggi, Giovanni: Il Duomo di Firenze: documenti sulla decorazione della Chiesa e del campanile tratti dall'archivio dell'opera [1909], 2 vols., ed. by Margaret Haines, Firenze 1988.

Roman, J.: Note sur une ancienne copie de la cène de Léonard de Vinci, in: Réunion des Sociétés des Beaux-Arts des départements, 1883, 58-65.

Rossi, Marco / Rovetta, Alessandro: Il Cenacolo di Leonardo. Cultura domenicana, iconografia eucaristica e tradizione lombarda, Milan 1988.

Samek Ludovici, Sergio: Bossi, Giuseppe, in: Dizionario Biografico degli Italiani, Roma 1971, vol. XIII, 314-319.

Sapegno, Natalino: Matteo Bandello, in: Dizionario Biografico degli Italiani, Roma, 1963, vol. V, 667-673.

Sedini, Domenico: Marco d'Oggiono tradizione e rinnovamento in Lombardia tra Quattrocento e Cinquecento, Roma 1989.

Sforza Galitzia, Sabrina: Il Cenacolo di Leonardo in Vaticano. Storia di un arazzo in seta e oro, Città del Vaticano 2009.

Shell, Janice/Brown, David Alan/Brambilla Barcilon, Pinin: Giampietrino e una copia cinquecentesca dell'Ultima Cena di Leonardo, Milan 1988.

Shell, Janice / Sironi, Grazioso: Documents for copies of the Cenacolo and the Virgin of the Rocks by Bramantino, Marco d'Oggiono, Bernardino de' Conti and Cesare Magni, in: Raccolta Vinciana, 23.1989, 104-117.

Shell, Janice: Pittori in bottega. Milano nel Rinascimento, Torino 1995.

Sironi, Grazioso: Appendice. Documenti inerenti il Bramantino, in: Arte Lombarda, 86/87.1988 (3/4), $37-42$.

Souchal, Geneviève: Le mécénat de la famille d'Amboise, in: Bulletin de la Société des Antiquaires de l'Ouest, 13.1976, 485-526 and 567-612.

Steinberg, Leo: Leonardo's Last Supper, in: The Art Quarterly, 36.1973 (4), 297-410.

Toscano, Gennaro: Le cardinal Georges d'Amboise (1460-1510) collectionneur et bibliophile, in: Les cardinaux de la Renaissance et la modernité artistique, ed. by Frédérique Lemerle, Yves Pauwels, and Gennaro Toscano, Villeneuve-d'Ascq 2009, 51-88.

Vasari, Giorgio: Trattato della pittura [1st ed. by Raffaele du Fresne, Paris 1651], ed. by G. G. De Rossi, Roma 1817.

Vasari, Giorgio: Le opere di Giorgio Vasari: Le vite de' più eccellenti pittori scultori ed architetti, 9 vols., ed. by Gaetano Milanesi, Firenze 1906-1910.

Vasari, Giorgio: The Lives of the Painters, Sculptors and Architects [1550-1568], 4 vols., ed. by J. M. Dent, London 1949-1950.

Viganò, Marino: Gian Giacomo Trivulzio e Bramantino: appunti su una committenza, in: Natale (ed.) 2017, 91-110. 